\title{
CONTRIBUTION OF HOME GARDENS TO HOUSEHOLD FOOD SECURITY IN SRI LANKA: A COMPARATIVE STUDY ON WET ZONE AND INTERMEDIATE ZONE
}

\author{
L.G.D.S. Yapa ${ }^{1}$
}

\section{Abstract}

In Sri Lanka, home gardens ensure to some extent the stability of household food security at the village level. Home gardening, which is an age-old practice in various parts of the country, varies on the basis of plant growth influenced by the seasonal weather changes, the composition of the soil and the structure of the locality. This paper attempts to identify the contribution of home gardens to food security with a focus on species richness and the availability of annual food supplement for family nutrition, as identified in a study carried out in four Agro Ecological Zones: the Kariyamadiththa and the Dambethalawa GN in the Intermediate Low Country (ILC); the Kumbalgama and the Silogama GN in the Intermediate Mid Country (IMC); the Vidulipura North and the Vidulipura South GN in the Wet Zone Up Country (WZUP); and the Dammala and the Pannimula GN in the Wet Zone Low Country (WZLC). The sample consists of 200 village level home gardens. While the sampling was random, the data analysis was carried out by means of SPSS 17.0 and the Shannon Diversity Index. According to the sample, the highest number of fruit varieties was found in the WZLC while the highest number of vegetable types was found in the WZUC. Most of the home gardens were maintained for both family consumption and marketing in the ILC. Animal husbandry was practiced sparsely but mostly in the ILC. Shannon diversity index shows that there are large variation in diversity and evenness among home gardens. The survey revealed that most of the householders did not have a reasonable knowledge about the seasons in which crops were available in their home gardens. The study highlights the importance of giving continuous incentives and identification of the potentials of the home gardens for increasing production to minimize the household food insecurity.

Keywords: Home gardens, crop diversification, agro-ecological zone, food security, family nutrient

\author{
${ }^{1}$ Department of Geography, \\ University of Ruhuna-Sri Lanka \\ sewwandika.yapa@gmail.com
}

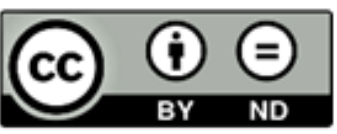

This article is published under the Creative Commons CC-BY-ND License (https://creativecommons.org/licenses/by-nd/4.0/). This license permits use, distribution and reproduction, commercial and non- commercial, provided that the original work is properly cited and is not change anyway. 


\section{INTRODUCTION}

Food security is a condition related to the on-going availability of food. According to the Food and Agriculture Organization (FAO), food security is defined as "a situation that exists when all people, at all times, have physical, social and economic access to sufficient, safe and nutritious food that meets their dietary needs and food preferences for an active and healthy life"( FAO,2017). In the case of Sri Lanka, out of the total estimated 1,134 grams of food consumed by an average person within a day, $35 \%$ comes from cereal and $15 \%$ from oil crops, $10 \%$ from fruits, $8 \%$ each milk and related products, vegetables and sugar products (Tennakoon, 2008).

In Sri Lanka, home gardens cover more than 13 percent of the land area. They are not only dwelling places but also an integral part of an agro-ecosystem. Home gardens are privately owned plots close to homesteads that are used for multiple purposes (Mattsson et al., 2017). The variety of crops and wild plants in them provides nutritional benefits. Home gardens are often characterized by the intensive use of multipurpose tree species, shrubs, food crops, and animals on the same piece of land at the same time (MacDicken and Vergara, 1990). They have a structural complexity and a multi-functionality that enable the provision of different benefits to ecosystems and people. Especially, rural families are engaged in food production for subsistence and small scale marketing which support family nutrition and sometimes household economy.

Home gardens emerge from the almost common practice of the occupants to plant trees around their habitations. However, for bigger gardens, farming labor is used to cultivate and manage (Dwivedi, 2000). Pushpakumara et al. (2012) revealed that the traditional management of home gardens in Sri Lanka is characterized by low inputs and simple technology. One reason for the low level of management in home gardens is the lack of labour availability due to the family members' involvement in other jobs.

However, with better management, the system has the potential for continuous production increases and better returns. The development of home gardens could be a win-win solution to food scarcity and sustainable village level livelihood activities in Sri Lanka. Pushpakumara et al., (2012) highlighted that home gardens are one effective way of ensuring access to a healthy diet that contains adequate macro and micro tropical nutrients to produce diverse kinds of foods in farming systems. This further revealed that Sri Lankan home gardens are dominated by food use species demonstrating their contribution to food plant diversity. There may be peaks and slack seasons for harvesting various crops from the home gardens depending on the climate and other environmental behaviours. However, there is usually something to harvest daily from most of the home gardens as they contain a large number of crops, trees and animal species. In addition, home gardens provide a considerable amount of household income, and it varies from a very low value to almost the total income for some families. This contribution comes mostly from the cash crops such as spices and timber trees. According to the consumer finance and socio-economic surveys, home gardens in the rural sector provide a higher contribution to the household income compared to those in the urban and estate sectors (Pushpakumara et al., 2012).

Today, the world faces a challenge of ensuring that millions of households living in poverty have access to enough food to maintain a healthy life. Sri Lanka is no longer in the "alarming" category according to the Global Hunger Index (GHI). This shows that Sri Lanka's food security at the national level has improved 
significantly. However, according to estimations, it revealed that 4.7 million people are under-nourished by 2015 especially including rural people (Wijeya Newspapers Ltd. 2004). Mattsson et al. (2013) focused on home gardens as a multifunctional land-use strategy in Sri Lanka with focus on carbon sequestration. This study explores the concept of home gardens and their potential functions as strategic elements in land-use planning, and adaptation and mitigation of the impacts of the climate change to Sri Lanka. This study indicated that the ancient and locally adapted agro-forestry system of home gardens is presently estimated to occupy nearly $15 \%$ of the land area of Sri Lanka and is described in scientific literature to offer several ecosystem services to its users; such as climate regulation, protection against natural hazards, enhanced land productivity and biological diversity, increased crop diversity and food security for the rural poor and hence reduced vulnerability to climate change. Therefore, it is important to see if national food availability has sufficiently ensured access to food at the village level household in different climatic zones.

Different types of home garden practices with agro biodiversity can be seen in the agro-ecological zones of Sri Lanka. The review of literature clearly showed that there is a lack of research on comparative studies among different climatic zones. Wet Zone (WZ), Dry Zone (DZ) and Intermediate Zone (IZ) home gardens are somewhat distinct from each other in species richness and their abundance. Although some research has focused on $\mathrm{WZ}$ and DZ home gardens, less attention is paid towards WZ and IZ home gardens. Therefore, this study focused on identifying the contribution of village level home gardens to food security in the WZ and the IZ of Sri Lanka.

\section{RESEARCH METHODOLOGY}

While the study focused on both primary and secondary data, a questionnaire survey was used mainly to collect primary data about some key concepts such as crops cultivation, food availability, home garden maintenance, soil conservation practices and home garden services for householders. While data collection was limited to four agro-ecological zones, naming IL1b and IM2a in IZ and WU 2a and WL in WZ, eight GN Divisions there namely Kariyamadiththa GN and Dambethalawa GN in ILC (IL1b), Kumbalgama GN and Silogama GN in IMC (IM 2a), Vidulipura North and Vidulipura South GN in WZUC (WU 2a) and Dammala GN and Pannimulla GN in WZLC (WL1a) were selected using random sampling method (Map 01).A simple random sampling was carried out to proportionally select the sample size of 200 village level home gardens in each GN Division. The secondary data were collected through research, articles, journals, books and internet. Moreover, observations were done to identify the structure of the home gardens and their maintenance.

Data was analyzed by using SPSS 17.0 software package and Microsoft Excel 2010. Pearson Correlation statistic method was used to identify the relationship between the land sizes and home gardens' contributions while percentage distribution method was employed for data presentation. Furthermore, the Shannon Index was used to find out the species richness (the number of species present) and their relative abundances (evenness) in home gardens. It was calculated using the equations following $\mathrm{H}^{\prime}=-\sum \mathrm{p}_{\mathrm{i}} \ln \mathrm{p}_{\mathrm{i}}$ and $\mathrm{H} / \mathrm{Hmax}$. Where, $\mathrm{H}$ is the Shannon Index and the quantity $p_{i}$ is the proportion of individuals found in the $i$ th species. 
Map 1: National and Regional Location of the Study Area

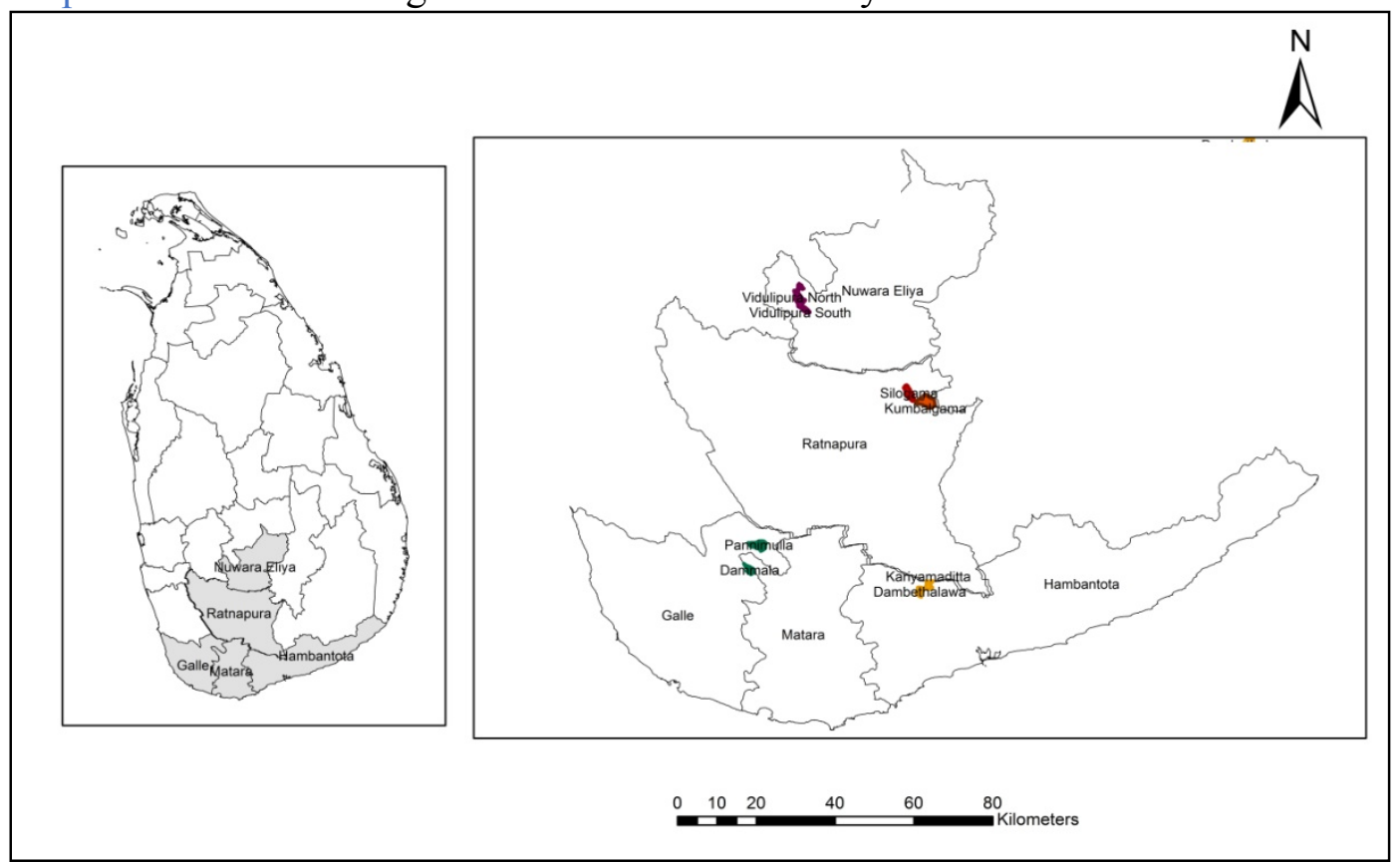

Source: Survey Department of Sri Lanka

\section{RESULTS AND FINDINGS}

Home gardens in different agro ecological zones are somewhat distinct according to their physiographic and climatic conditions. But it usually occupies an area close to houses and it consists of a number of crops having several functions. In these home gardens, the upper story is often of trees that produce timber, fuel wood, fruits, shade and food. The middle story may produce fruits, pepper, cinnamon, curry leaves etc. The understory may consist of vegetables, a verity of herbs, ornamental plants, fodder etc. Home gardens land size is very significant as it helps to determine how far householders used land for their maximum benefits. In WZ, $32 \%$ of home gardens have less than half an acre while in ILC, $6 \%$ of home gardens have less than half an acre. Commonly, the majority of the home garden sizes of ILC, IMC, WZUC and WZLC ranges between more than half acres to less than one acre. It accounts for $34 \%, 38 \%, 30 \%$ and $48 \%$ collectively.
It is significant that in theses agro ecological zones, the majority of home gardens were maintained by using family labors. It accounts for $88 \%$ in IMC, $74 \%$ in WZLC, $62 \%$ in ILC and $40 \%$ in WZUC. Moreover, the survey revealed that $42 \%$ of home gardens in WZUC, 30\% in ILC, $16 \%$ in WZLC and 12\% in IMC were maintained by using both family and hire labour. Soil conservation methods were used in WZUC and WZLC to control soil erosion and maintain home gardens productivity. It accounts for $98 \%$ and $90 \%$ respectively. Further, in ILC and IMC, home garden owners' had used soil conservation strategies to control soil erosion constituting $52 \%$ and $68 \%$ respectively.

Proper maintenance of home gardens with various crops is helpful to improve families' nutritional supplement as it supplies the minerals, fiber, vitamins, carbohydrates, protein as a nutrients to the family. These energies ensure the families' food security throughout life. According to the survey, the sitting of the plants were rather haphazard in the study areas. 44 vegetable varieties in the home gardens 
were recorded. 14 of total vegetable crops were common to the study area. Those are Manioc(Manihot esculenta), Sweet potato (Ipomoea batatas), Kiriala, Ladies fingers (Abelmoschus esculentus), Green chilli (Capsicum), Winged bean (Psophocarpus tetragonolobus), Tomato (Solanum lycopersicum), Batu (Solanum nigrum), Malumiris (Capsicum annuum), Long beans (Vigna unguiculata), Jack fruit (Artocarpus heterophyllus), Breadfruit (Artocarpus altilis), karawila (Momordicacharantia L.), kathurumurunga (Sesbania grandiflora) and Pumpkin (Cucurbita maxima). In addition to that, Gahala (Colocasia esculenta), Thibbatu (Solanum torvum) and Inala (Plectranthus rotundifolius) were grown in ILC and WZLC home gardens. Brinjal (Solanum macrocarpon), Drumstick (Moringa oleifera) and Ridge Gourd (Luffa acutangula) were common in ILC, IMC and WZLC home gardens. In IMC and WZUC home gardens, Beans (Phaseolus vulgaris), Valala (Colocasia amplifolia) and Turnip (Brassica rapa) were grown. Cucumber (Cucumis sativus), labu (Lagenaria siceraria) and Atukakiri (Cucumis melo) could be found in ILC home gardens. The Shannon Diversity Index value of 2.83, 2.69, 2.92, and 2.78 for the sample areas following ILC, IMC, WZUC and WZLC indicated that there exist large variations in species diversity. An evenness value of $0.75,0.71,0.78$, and 0.73 for the above sample areas indicated that the even distribution of different species in the area. Further, the survey was found that January, March, April and May were the months, which were available vegetables mostly in WZUC home gardens (Figure 01). There were no any special months for vegetable cultivation in ILC as they used irrigation methods to cultivate during the drought. Different types of yields are available in different seasons depending on climate and environmental characteristics.
Leafy green vegetables, main source of iron and calcium, provide number of benefits to human health. According to the survey, 15 leafy green vegetable varieties were recorded in home gardens. Gotukola (Centella asiatica), Mukunuwanna (Alternanthera sessilis), Nivithi (Malabar spinach), Thampala and Kankun (Water spinach) were most common leafy green vegetables in home gardens. Kowakka (Ivy gourd), Thebu (Costus speciosus) and Asamodagam were available in ILC and WZUC home gardens. Kirihanda, Neeramulli, Penela and Kalukamberiya were common to WZUC home gardens.

Furthermore, in these zones, 34 fruit varieties were identified: 11 of them were common to all four zones. Those were Banana (Musa), Pear (Pyrus), Mango (Mangifera indica), Rose apple (Syzygium samarangense), Papaya (Carica papaya), Orange (Citrus reticulate), Rabutan (Nephelium lappaceum), Delum (Punica granatum), sweet lemon(Citrus reticulate) and Avacado (Persea americana). In addition, Lavalu (Pouteria campechiana), Mangosteen (Garcinia mangostana), Ugurassa (Flacourtia indica) andVeralu (Elaeocarpus serratus) were common to IMC, WZUC and WZLC. Pinnaple (Ananas comosus), Beli (Aegle marmelos) and Kabaranka (Averrhoa carambola) were planted in ILC, IMC and WZLC home gardens while Sugarcane and Lokat were found in IMC home gardens. Shannon Diversity Index shows that there exists a large variation in diversity and evenness among home gardens. It accounts for Shannon Index value of 2.53, 2.59, 2.67 and 2.89 and evenness value of $0.71,0.73,0.75$ and 0.81 for ILC, IMC, WZUC and WZLC home gardens respectively. 
Figure 1:Monthly Availability of Vegetables in Home gardens

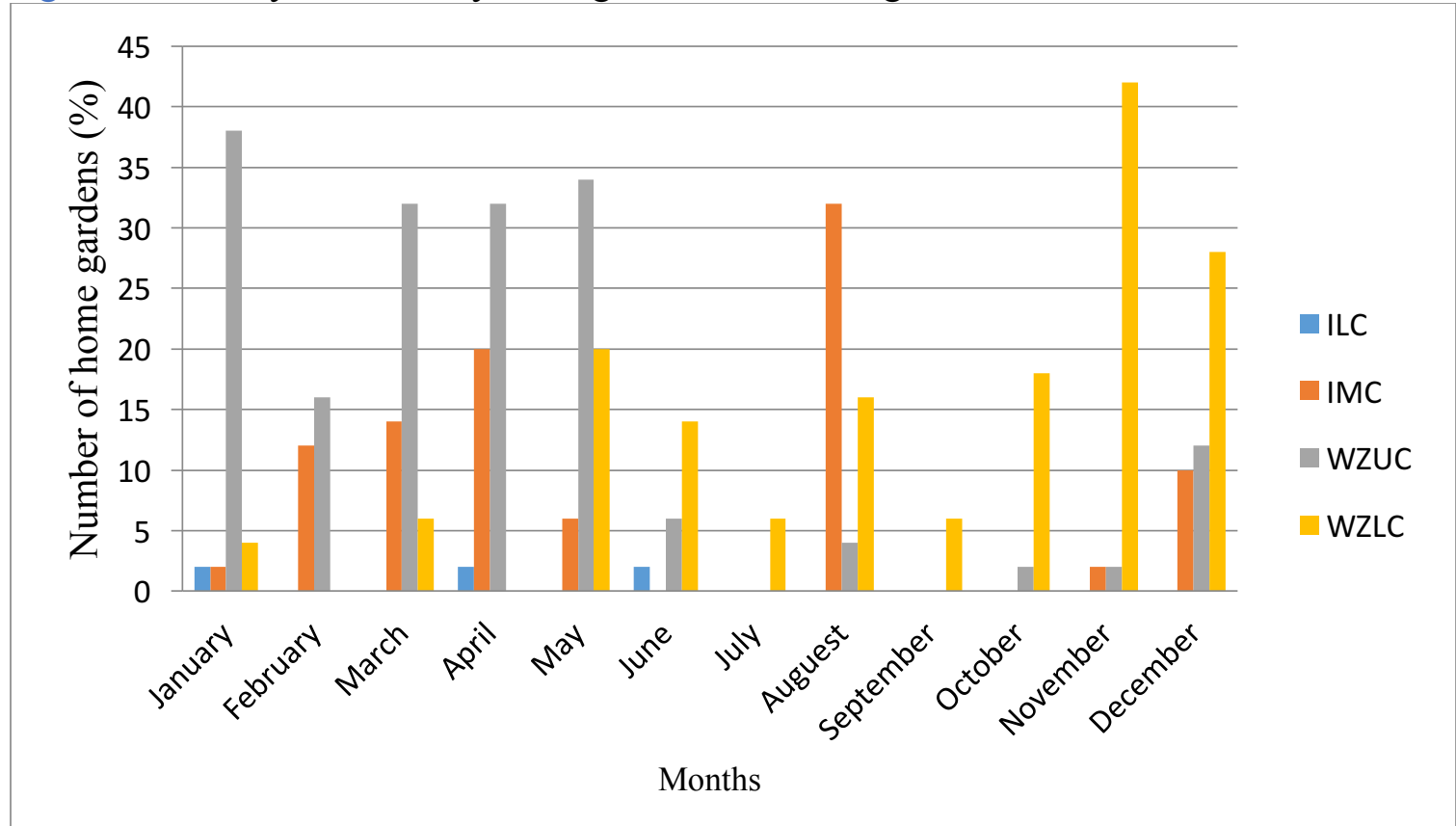

Source: Field survey, 2016

Figure 02: Monthly Availability of Fruits in Home gardens

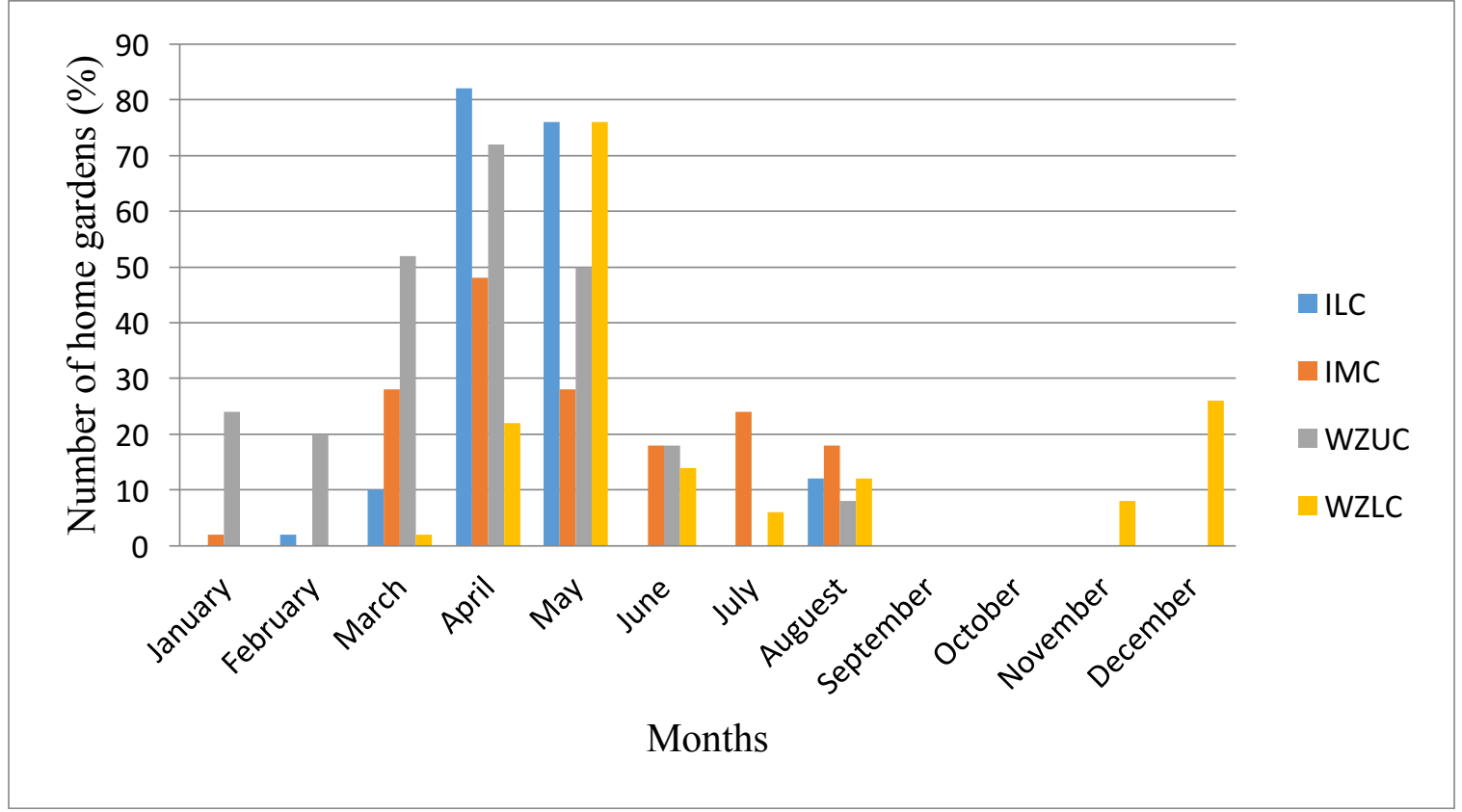

Source: Field survey, 2016

According to figure 02, it reveals the fruits were available in March, April, May and August in these four zones generally. $82 \%$ and $76 \%$ of home gardens in ILC are having fruits yield in April and May while in IMC majority of home gardens (48\%) are having fruits in April. 72\%, 52\% and 50\% of home gardens in WZUC are having fruits in April, March and May respectively. Though January and June are the months when fruits are available for some families 
in IMC and WZUC, no fruits are available in January, June and July in ILC home gardens.

Plantation crops such as coconut (Cocos nucifera), pepper (Piper nigrum) and cinnamon (Cinnamomum dubium) were planted in the periphery of the home gardens in each zone for consumption and market basis. $88 \%$ home gardens in IMC were cultivated pepper and $100 \%$ home gardens were cultivated coconut in ILC home gardens. $48 \%$ of home gardens were having cinnamon in WZLC. Curry leaves (Murraya koenigii), Rampe (Pandanus amaryllifolius), Sera leaves (Cymbopogon citratus), Nutmeg (Myristica fragrans), Clove (Syzygium aromaticum) and Cardamom (Elettaria cardamomum) were the spices which could be seen in each zone home gardens. Moreover, 37 herb varieties in all zones' home gardens could be identified through the survey. 14 varieties in ILC, 20 varieties in IMC, 22 varieties in WZUC and 28 varieties in WZLC home gardens. Betel (Piper betle), Polpala (Aervalanata), Turmeric (Curcuma domestica), Hathawariya (Asparagus racemosus), Komarika (Aloe vera), Igurupiyali (Kaempferia galangal), Ginger and Neem tree (Azadirachta indica) were common in all these four zones. Theleradu (Adhatoda vasica), Nika (Vitexnegundo L) Indian gooseberry (Phyllanthus emblica) were common to IMC, WZUC and WZLC home gardens.

In addition, in some home gardens, crops trees were mixed with livestock. Animals such as chicken, cattle and goats are reared in some householders. Animals were reared more in ILC and WLC home gardens than others. It accounts as $18 \%$ of hens, $30 \%$ of cows and $2 \%$ of goats in ILC and $10 \%$ of hens and $14 \%$ of cows in WLC. There were no any goats rearing in IMC and WZLC home gardens. A significant difference could be identified regarding the benefits of the home gardens between family consumption and market basis. 98\%, 72\%,
$72 \%$ and $34 \%$ of home gardens were maintained for both family consumption and market basis in ILC and IMC and WZUC and WZLC. Furthermore, 2\%, $28 \%, 26 \%$ and $64 \%$ were used only for family consumption in ILC and IMC and WZUC and WZLC respectively.

Timber crops, which are cultivated in home gardens, provide number of benefits to the householders. Accordingly, the survey revealed that 21 species of timber crops types were planted in these home gardens. Jackfruit and Mahogani were common to all zones while Halmilla, Sapu, Mee, Milla, Akeshiya, Kududawula and Maadan were available in IMC home gardens. Turpentine, Tuna, Ibul, Gandis and Sawarinnuga were cultivated in the IMC home gardens.

Pearson Chi square shows that there is no relationship between land size with number of cultivation, number of cash crops and services obtained from home gardens in ILC. The $\mathrm{P}$ value is $.115, .121$ and .576 $(<0.05)$ flowingly and it means $\mathrm{H} 0$ is not rejected. Accordingly, other three zones also were depicted that no relationship between land size and number of cultivation crops. Moreover, Shannon index value shows that there is a large variation of species richness (like fruits, vegetables, spices, plantation crops, cereals, and pulses) and evenness in their abundance. It accounts for 1.31, 1.28, 1.23 and 1.16 of Shannon index values and 0.94 , $0.92,0.98$ and 0.83 of evenness values for ILC, IMC, WZUC and WZLC respectively. So, this study revealed that sustainable maintenance of home gardens totally depends on householders' preferences than environmental conditions.

\section{CONCLUSIONS}

Different types of home garden species could be seen in Sri Lanka according to agro-ecological zones. WZ and IZ home gardens are vary from one to another. Homestead plantations in these study areas 
indicated that a number of fruits, vegetables, timber trees, shade trees, spice, herbs and cereals. More crop varieties such as vegetables, leafy vegetables, cereals, and pulses were planted in WZ and IZ home gardens. 26 Fruit varieties, 28 herbs varieties in WZLC while 30 vegetable varieties, 12 leafy vegetables, 8 flavors, and spices were found in WZUC home gardens. Shannon Diversity Index showed the value of above 0.1 and it was clear that home gardens in these zones having multi-layered system with high species richness and evenness. Although WZ home gardens had number of varieties of crops, number of crops per home gardens was high in ILC zone. However, these varieties of crops provide the seasonal foods for home gardens' owners. There may be peaks and low seasons for harvesting various products from the home gardens depending on the climate and other environmental characteristics. However, there is usually something to harvest daily from most of the home gardens as they contain a large number of crop, trees and animal species. January, March, April and May were the months of peak seasons of available vegetables and fruits while September and October were the low season of available foods in these home gardens. Home garden owners might not selected species on the basis of high yield or targeting their nutrient supplement. However, such a home garden system supports much to secure food availability by diversification of crops cultivations and sometimes for their economy and it also supports to enhance the quality of life of the people. This study suggests the needs of giving continuous incentives, provision of hybrid seeds and identification of potentials of home gardens to sustainable management.

\section{ACKNOWLEDGEMENT}

The author would like to thank Dr. H.I.G.C. Kumara, Senior Lecturer in the Department of Geography, Universitof Ruhuna for his valuable assistance to collect literature. Furthermore, the author thanks Mrs. Sadaruwani Sumanapala and Mr. Pathum Sampath in the Department of Geography and Environmental Sciences, Sabaragamuwa University of Sri Lanka for supporting to collect data in the field.

\section{REFERENCES}

Dwivedi A.P.(2000). Agroforestry: Principles and Practices. New Delhi: Oxford \& IBH Publishong Co-PVT. LTD.

FAO(2017).Food Security: concept and measurement. Retrieved fromhttp://www.fao.org/docrep/005/y4 671e/y4671e06.htm.

MacDicken K.G. and Vergara N.T.(1990).Agro-forestry:

Classification and Management. New York:A Wiley Inter science Publication.

Mattsson E.,Ostwald M., Nissanka S.P. and Marambe B.(2013).Home gardens as a Multi-functional Land use Strategy in Sri Lanka with Focus on Carbon Sequestration. Retrieved from https://www.researchgate.net/publicati on/236590538_Homegardens_as_a_M ulti-functional_Land-

Use_Strategy_in_Sri_Lanka_with_Foc us_on_Carbon_Sequestration.

Mattsson E., Ostwald M. and Nissanka S.P.(2017). What do know about food security in home gardens in Sri Lanka? Retrieved from https://www.researchgate.net/publicati on/317570660_What_do_we_know_ab out_food_security_in_homegardens_of _Sri_Lanka.

Pushpakumara D.K.N.G., Marambe B. and Weerahewa J.(2012).A Review Research on Home gardens in Sri Lanka: the status, importance and Future Perspective. Retrieved 
fromhttps://www.researchgate.net/publ ication/236117466_A_review_research _on_homegardens_in_Sri_Lanka_the status_importance_and_future_perspec tive.

Tennakoon A.(2008).Sri Lankan Economy in Transition: Progress, Problems and Prospects. Colombo: Vijitha Yapa Publication.

Wijeya Newspapers Ltd.(2004).Mirror Business. Retrieved fromhttp://www.dailymirror.lk/94013/f ood-security-does-it-matter-for-srilanka. 